\title{
Democratization of President Selection Systems Directly and Indirectly in Indonesia
}

\author{
Ilham Adhyatma*, Ellydar Chaidir, Sri Wahyuni \\ Faculty of Law \\ Universitas Islam Riau \\ Pekanbaru, Indonesia \\ *ilhamadhyatma.id@gmail.com, ellydar@law.uir.ac.id, sriwahyuni@law.uir.ac.id
}

\begin{abstract}
The people's disapproval of the presidential election system during the New Order era was due to the fact that it was deemed less democratic and had the potential to produce authoritarian leaders, so that is an indication of the many problems that eventually led to constitutional changes or the 1945 Constitution Amendment. The issues raised in this study are the democratization of the New Order President's election system with the Reformation Age and the implications of the President's direct election system for democracy in Indonesia. The research the authors do is included in the type of normative legal research. This study concluded that during the New Order era the President was elected by the "Majelis Permusyawaratan Rakyat" (MPR), by using a voting system and only MPR members had voting rights. So that this system is considered less democratic. The implication of the direct election of the President for democracy in Indonesia is the emergence of regional disintegrative attitudes.
\end{abstract}

\section{Keywords—democratization, presidential election system}

\section{INTRODUCTION}

New Order, the sovereignty of the people is held by a body called the Majelis Permusyawaratan Rakyat (People's Consultative Assembly) as representative for whole Indonesian people [1]. Majelis Permusyawaratan Rakyat (MPR) before the 1945 Constitution Amendment had the task of preparing the Constitution and establish Garis Besar Haluan Negara (GBHN). The MPR at that time also had the prerogative to appoint a Head of State or President and Vice President. During the New Order era, the presidential and vice presidential election system was chosen by the MPR with a voting system based on the most votes. The resignation of President Soeharto shows that the people no longer agree with the presidential election system which was implemented indirectly. The people's disapproval of the presidential election system during the New Order era was due to the fact that it was considered less democratic and had the potential to produce authoritarian leaders who did not respect human rights. That is one indication of the many problems that eventually led to changes in the constitution or amendments to the 1945's Constitution.
The democratization of elections based on the current system needs to be reexamined because democracy is one of the issues that emerged after the fall of the New Order regime. In its implementation, whether we realize it or not, the current democratic system is still far from being the substance of democracy itself [2].

\section{METHODS}

This research is included in the category of normative legal research using secondary data, which consists of primary legal materials, secondary legal materials, and tertiary legal materials. With regard to primary legal materials, the authors analyze the laws and regulations related to the presidential election system. Furthermore, secondary legal materials, which are used in this article, are journal articles, books, and research results that have a correlation with this research. Furthermore, the tertiary legal material used in this study is a legal dictionary that is relevant to the issues raised. Then, the authors collect data based on a study of documents in the form of books, journals and other literatures that the authors obtain through the literature [3].

The nature of this research is descriptive in nature, namely the author intends to describe systematically the Democratization of the Presidential Election System Directly and Indirectly in Indonesia. Furthermore, it is analyzed qualitatively by describing it clearly, then comparing the data with the provisions of laws and regulations as well as the opinions of legal experts. Conclusion drawing is done in a deductive way, namely the inference from general matters to specific matters [4].

\section{RESULTS AND DISCUSSION}

Republicanism implies government that is administered from the people and for the benefit of all the people in that country. The administration of state institutions in the republic must always be implemented for the public interest. The head of state as one of the leaders of an office in the republican government must show the will of the public interest and every decision is determined based on the public will as well [5]. 
The Republic of Indonesia has widely used various systems for the election of President and Vice President. Starting with the election of the first President Ir. Soekarno until the election of Ir. Joko Widodo as the seventh President of Indonesia. From 1945 after independence until now, the presidential election system has undergone many changes in line with the amendments to the 1945 Constitution with the aim of creating a democratic electoral system. Indonesia has experienced the Presidential and Vice-Presidential election system in three eras which divided from the Old Order period (Before the Amendment of the 1945 Constitution, namely the era of President Soeharto), Before the Amendment of the 1945 Constitution) to the Reformation Age (after the Amendment of the 1945 Constitution) which we are experiencing today. From the New Order era until the amendment of the 1945 Constitution was born the Reformation Age as a very influential foundation for the progress of this nation. This is marked by changes in the Indonesian democratic system, namely the direct election of the President by the people with rights guaranteed by the Constitution or the 1945 Constitution [6].

This is the point of progress of democracy in Indonesia which is in line with the substance of democracy, that government is administered from the people, by the people, and for the people [7]. The democratic system in Indonesia must be continuously monitored and supervised by every group so that real democracy is expected to be realized. The experience of democracy in Indonesia is still relatively new, so there are still many deficiencies in its implementation. It turned out that Indonesia had bitter experiences in democracy and governance during the New Order regime, which was very anti-democratic, tended to be authoritarian and dictatorial. The government at that time was run repressively. The famous sentence from Lord Acton said that "power tends to be corrupt, absolute power corrupts absolutely", affecting the whole New Order regime under President Soeharto [8].

Soekarno's fall in the mid-60s was marked by the beginning of Soeharto's reign, which was appointed by the MPR as the mandate holder for the presidency in a special session of the MPR. The 1945 Constitution of the Republic of Indonesia regulates in general the holding of the election for the President and Vice President. Article 6 paragraph 2 (before the 1945 Constitution Amendment) states that the President and Vice President are elected by the People's Consultative Assembly (MPR) with the most votes. The MPR members consist of members of the People's Representative Council plus representatives from regions and groups. As stated in Article 2 paragraph (1) of the 1945 Constitution. Why was the 1945 Constitution amended? The elementary answer is that with the 1945 Constitution, the practice of organizing the life of the nation and state always creates authoritarian, corrupt and undemocratic governments. Although the conditions for the formation of a populist, clean and democratic government are not only determined by the constitution. As Maswadi Rauf said, "Democratization is a never-ending process because it is related to efforts to uphold democratic values" [9].
The arguments above are actually quite reasonable, with the assumption that because the constitution contains basic laws, basic principles in the administration of a state and determining the goals of the nation and state, it will be anchored [10]. Various kinds of analysis results submitted by analysts and experts from various universities and the wider community, the Presidential election system indirectly through the MPR needs to be reviewed and replaced with another system that is more democratic. They are of the opinion that the election through the MPR opens up opportunities for unhealthy cow trade politics to negate the will of the people's voice, even though the people's voice is the core of democracy [11].

One of the important things that was done during the democratic transition period, according to Larry Diamond, was the revitalization of the functions of political institutions so that they could work more democratically, the extent to which the executive, legislature and other democratic institutions such as political parties and general elections could work in accordance with the principles. democratic principles so that they can be a driving factor for the growth of democracy. The functions of each political institution are usually regulated in the basic law of the country which is called the constitution. In this context, improving or renewing the basic rules of the state is a necessity in democratic transition. The idea of a direct presidential election emerged in line with the discourse on the need to develop a new, more democratic political format in Indonesia as a demand for political reform.

The author's more democratic analysis between the three periods is during the Reformation period (after the 1945 Constitution Amendment), namely the direct presidential election system. So the classic question arises: Why is the PostAmendment Presidential and Vice-Presidential Election System considered to be more democratic? The simple answer is because direct elections open the door to the appearance of a President and Vice President who are in accordance with the wishes of the majority of the people themselves. In addition, in direct Presidential elections, it will be very difficult for the President / Vice President to deviate from using money politics to win. Besides that he will not be able to pay the people one by one, such actions will certainly be easier for the public to know, so that the public can judge their future leaders. Unlike the case with the Presidential and Vice-Presidential election system stipulated by the 1945 Constitution before the Amendment, namely through voting in the MPR which was considered less democratic, the majority party would always occupy the seat of power because it did not involve all Indonesian people in the election process.

Every Presidential and Vice-Presidential election system that has been implemented in Indonesia, of course, the author believes there must be advantages and disadvantages. Therefore, the authors agree more that the presidential election system is implemented directly for the reasons that the authors have stated above. However, the weaknesses that exist in the direct electoral system are not the means and attempts to undermine the system we are using in this reform. It is enough 
as a comparison and learning for all of us to perfect these weaknesses.

According to Moh. Mahfud MD, the direct election system for President and Vice President is more democratic. But there are things that are very important and of concern, why should the direct election system be implemented. In the track record of the Indonesian state, according to him the direct election system is more transparent with the appearance of the President and Vice President according to the choice of the majority of the people themselves. When viewed from the results of the presidential election in 1999 , the reality that the political choices of the people for the presidential candidates proposed by political parties are different from the wishes of their representatives in the MPR who have the formal right to elect the President [12].

What has been described above shows that there are sufficiently strong arguments for the direct election of the President and Vice President by all the people, namely: to bring up the President and Vice President that the people really want; to avoid money politics and minimize job transactions; and to further ensure the stability of government.

The direct election of the President and Vice President during the reform era does not mean that it does not have weaknesses or implications, although this is still a hypothesis. A number of weaknesses must be anticipated from an early age for the future so that the implementation of this direct election does not become a delay that creates difficulties and may occur. The direct implication of the presidential election system that needs to be anticipated is that the people vote based on SARA and certain regions which give rise to a regional disintegrative attitude in implementing democracy. The Indonesian state is rich in religious and ethnic plurality, there can be a possibility that voters in certain areas will elect almost one hundred percent of certain candidates for President / Vice President based on religion or ethnicity and the area of residence. Of course, this will have an impact on the results of the Presidential and Vice-Presidential elections in these areas which can be very unbalanced if you look at this aspect by ignoring the programs presented by the Presidential candidates. For regions where the adherents of religion are more heterogeneous and tolerant such as in Java, for example, this problem will not be too worrying. However, if you look at areas where the religion is almost homogeneous, such as Bali, NTT, North Sulawesi, Irian Jaya, North Maluku, West Sumatra, Nangroe Aceh Darussalam, for example, it is likely that the candidates who are elected and won are those who embrace a religion. the majority of the population in their respective areas. Things like this are common and can happen in a pluralistic nation-state like Indonesia. Looking back at the 2004 presidential election contestation, there were many hot issues related to this issue, such as the issue of candidate pairs surrounded by followers of certain religions or the issue of candidates making policies that harm people of certain religions. This is what causes the implementation of democracy in the Indonesian state, some of the people have not been able to see further that in fact the most important thing is how we can see the programs or vision and mission campaigned by the presidential candidate so that things that are theological, ethnic, racial and regions are put aside first for the advancement of this nation and country in order to create quality democracy.

It should be noted that, religion, ethnicity and race are used as political weapons in the constellation of democracy at this time. This certainly injures our democracy which will affect the people's choice in determining their democratic rights. Ahead of the presidential election contest, many candidates came to mosques, Islamic boarding schools and other places of worship to convey their campaign programs. Things like this not only injure democracy but also injure the existence of religion. The places of worship and places of education should not be used as an arena for politics.

Considering that the level of awareness of the Indonesian people in democracy is still not good, this implication has the potential to provoke thoughts of disintegration. In addition, there are many people's concerns when implementing a direct presidential election system that assumes that the Javanese ethnic will always be elected, thus minimizing the chances of a President from another ethnicity outside of the Javanese ethnicity. This concern is based on the fact that most of Indonesia's population resides in Java. It cannot be denied that during the election contest the majority of the elected President are people from Java. This is an indication that regions with a small population may not be able to compete for the presidential throne, this is also an important note of the implications of direct democracy.

\section{CONCLUSION}

This research concludes that during the New Order era the President was elected by the People's Consultative Council (MPR) using a voting system and only MPR members had the right to vote. So that this system is considered less democratic because it is determined by political power and tends to produce an authoritarian President. Meanwhile, in the Reform President election system, the President and Vice President are directly elected by all Indonesian people based on majority votes. So that this system better reflects the nature of transparency and democracy. The implication of the direct presidential election for democracy in Indonesia is the emergence of a regional disintegrative attitude. Seeing the reality of the plurality of religions and ethnicities in Indonesia, some people in certain areas prioritize the principle of equality with religion, ethnicity and region in choosing presidential candidate pairs. In addition, there are many people's concerns when implementing a direct presidential election system that assumes that the Javanese ethnic will always be elected, thus minimizing the chances of a President from another ethnicity outside of the Javanese ethnicity. This concern is based on the fact that most of Indonesia's population resides in Java. It cannot be denied that during the contestation of the presidential election, the majority who are elected are people from Java. This is an indication that regions with a small population will not be able to compete for the presidential throne, this is also an important note of the implications of direct democracy. 


\section{REFERENCES}

[1] Tim Eska Media, Edisi Lengkap UUD 1945. jakarta: Eska Media, 2002.

[2] Y.E. Nurhuddin, "General Election in the Fourth Precept Pancasila Perspective Democracy System," Cakrawala Huk. J., vol. 8, no. 2, p. 242, 2018.

[3] Z. Amiruddin \& Asikin, "Pengantar Metode Penelitian Hukum," Jakarta Raja Graf. Persada, 2004.

[4] S.M. Soerjono Soekanto, "Penelitian Hukum Normatif, Suatu Tinjauan Singkat.” Jakarta: PT Raja Grafindo Persada, 2003.

[5] U. Rauta, "Initiating a Democratic and Aspirational Presidential Election," J. Const., vol. 11, no. 2, p. 605, 2014.

[6] J. Asshiddiqie and B. Manan, Gagasan amandemen UUD 1945 dan pemilihan presiden secara langsung. Setjen \& Kepaniteraan, Mahkamah Konstitusi RI, 2006.
[7] S. Haris, Menggugat pemilihan umum Orde Baru: sebuah bunga rampai. Yayasan Obor Indonesia dan PPW-LIPI, 1998.

[8] R.K. Iskandar, "Towards Democratization of Presidential Election," J. Mimb. Soc. Dev., vol. 19, no. 1, p. 1, 2003.

[9] M. Rauf, Demokrasi dan Demokratisasi: Penjajakan Teoritis untuk Indonesia. Jakarta: Indonesia: Seri Penerbitan Studi Politik Kerja sama Laboratorium Ilmu Politik FISIP-UI with Mizan, 1998.

[10] D. Thaib, Teori dan Hukum Konstitusi. Jakarta: Indonesia: PT RajaGrafindo Persada, 2006.

[11] V.S. Subekti, Menyusun Konstitusi Transisi. Jakarta: Indonesia: PT Raja Grafindo Persada, 2008.

[12] M. Mahfud, "Demokrasi Dan Konstitusi Di Indonesia: Studi Tentang Interaksi Politik Dan Kehidupan Ketatanegaraan/Prof. Dr. Moh. Mahfud MD," 2003 . 